\title{
Impact of Pesticides Malathion and Sevin on Growth of Snake Cucumber (Cucumis melo L. var. Flexuosus) and Soil
}

\author{
M.O. Gafar, A. Z. Elhag*, M.A. Abdelgader \\ Sudan university of Science and Technology, Sudan \\ *Corresponding Author:zadhag@yahoo.com
}

Copyright (C) 2013 Horizon Research Publishing All rights reserved.

\begin{abstract}
This study was conducted at the College of Agricultural Studies, Sudan University of Science and Technology Farm to evaluate the impact of Malathion, an organophosphate insecticide, and Sevin, a carbamate insecticide, on the growth of snake cucumber and soil. . The results revealed that both Malathion and Sevin had significant negative effects on cucumber growth (plant height, leaf number and shoot fresh and dry weight) at all doses used compared to control. However, the recommended dose showed the lowest negative effect compared to both lower and higher doses used. Both pesticides had also negative effects on the soil as they reduced both soil nitrogen (by 36\%) and phosphorus ( by20\%) contents as well as its CEC. They also increased soil aggregate and salinity. Malathion showed the greater impact on growth compared to Sevin. However, it could be recommended that for use of both pesticides on cucumber not more than the recommended dose should be applied.
\end{abstract}

Keywords Malathion, Sevin, Residual Effect, Soil, Cucumis Melo, Growth

\section{Introduction}

Snake cucumber (Cucumis melo L., var. flexuosus) belongs to the family Cucurbitaceae. It is of high moisture content and rich in vitamins (A, C and B complex) and minerals (calcium, iron, magnesium, phosphorus, potassium and zinc), in addition to sugars and other carbohydrates. It is widely grown in Sudan and comprises with other cucurbits about 5\% (14000 ha) of the average area under vegetables (Anon., 2008). It is attacked by many pests and diseases (beetles and fungal diseases) which are mainly chemically controlled (using pesticides and fungicides).

Pesticides Malathion (organophosphate) and Sevin (carbamate) are the main pesticides used in Sudan. Their excessive use results in a great damage to the ecosystem. Zaki (1978) stated that some pesticides might undergo a lot of changes and become more toxic. Most soils under field and vegetable crops and forests were contaminated with pesticides residuals ( Lichtenstein et al., 1962, Bartha et al., 1967 and Gigliotti and Allievi, 2001). Omer (2001) found high amount of pesticides in the soil (0.0156ppm of Sevin). Despite that Organo Chlorine pesticides were banned or restricted in many countries, they are still detected in soils (Pimentel, 2005, Gillium, 2007, Maltby and Hills, 2008 and Ferencz and Balog 2010). Farenhorst (2006) stated that adsorption was the most important factor which limits pesticides degradation as well as their transport into the soil. Soil organic matter is the most important factor influencing sorption and leaching of pesticides in soil. Soils rich on humus content are more chemically reactive with pesticides than nonhumified ones. Potera (2007) and Shahla and D'Souza (2010) reported that change in soil $\mathrm{pH}$, addition of nitrate fertilizers or soil organisms induced the release of pesticides residues.

Crop pollution refers to the crop phytotoxicity resulted from pesticide applications. It affects crop growth and reduces its yield and quality. Pesticide residues have been detected in grains, vegetables, fruits, tea and medicinal herbs (Gafar et al., 2010). Adsorption is one of the most important factors that affects fate of pesticide in soils and determines their distribution in the soil/water environment (Relyea, 2005).

However about one-third of the agricultural products are produced by using pesticides (Pimentel 2005). Without pesticide application the loss of fruits, vegetables and cereals from pest injury would reach $78 \%, 54 \%$ and $32 \%$ respectively crop loss from pests declines to $35 \%$ to $42 \%$ when Pesticides are used (Pimentel, 1997). In view of the world's limited croplands and growing population, it is necessary to take all measures to increase crop production in order to ensure food safety (Longley and Sotherton, 1997, Guo, 2006 and Maltby and Hills, 2008), This study was conducted to investigate the residual effects of both pesticides Malathion and Sevin on soil and cucumber growth, yield and quality. 


\section{Materials and Methods}

This study was conducted in at the Experimental Farm (380m above sea level), College of Agricultural Studies, Sudan University of Science and Technology to investigate the residual effect of pesticides Malthion and Sevin on soil and snake cucumber growth, yield and quality. The crop was grown on ridges $2 \mathrm{~m}$ apart and $50 \mathrm{~cm}$ between plants. It was fertilized with $300 \mathrm{~kg}$ urea/ha. A month from planting, the plants were sprayed with three separate doses of Malathion and Sevin which comprised the six treatments studied. Pesticides concentration were $0.95,1.8$ and $2.85 \mathrm{~kg} \mathrm{ha}^{-1}$ each of Malathion and Sevin, resembling the lowest, the recommend and the highest doses of each, respectively. Other cultural practices till the crop harvest were done as recommended. The experimental units were in completely randomized block design in four replications. Soil samples were collected at $30 \mathrm{~cm}$ depth before and after pesticides treatment and analyzed for $\mathrm{pH}$, Electrical conductivity(EC.), organic carbon, total nitrogen, carbon nitrogen ratio $(\mathrm{C} / \mathrm{N})$ and Cation Exchange Capacity (CEC).

Ten randomly selected plants were pulled out washed and their vegetative growth was evaluated as plant height, number of leaves, leaf area and shoot fresh and dry weight. The means were compared using LSD at $\mathrm{p} \leq 0.05$

\section{Results and Discussion}

The results revealed that both Malathion (Table1) and Sevin(Table2) had significant negative effects on cucumber growth. The plant height was reduced by $43-47 \%$ and $71 \%$ at the higher and the lower doses of both herbicides, respectively, compared to control, whereas, the reduction was only $16-23 \%$ at the recommended doses of both pesticides. The same negative effects were noticed on other growth parameters (leaf number and area and shoot fresh and dry weight). In addition to pesticides effects on plant growth they had also affected both soil physical and chemical characteristics (Table3). The soil sand content was increased by 2.5 times by pesticide application, whereas, its silt and cay contents were reduced by $44 \%$ and $10 \%$, respectively. Both soil $\mathrm{pH}$ and Ece. were slightly increased, while its available nitrogen and phosphorus were reduced by $36 \%$ ) and by $20 \%$, respectively. Also its organic carbon and CEC. were slightly reduced. Thus the reduction on plant growth could be attributed to the pesticides toxicity at the higher doses and their effects on both soil physical and chemical characteristics in addition to damage of pests at the lower pesticides doses. Similar results were obtained by Gafer et al. (2010, 2011and 2012) on some other vegetables using the same pesticides and doses. Also Abdel-Gawad (2010) reported that pesticides affected crop growth and reduces its yield and quality due to their phytotoxicity and also due to their effects on soil fertility and salinity as stated by Lang and Cai (2009).

Moreover, Bartha et al. (1967), Mallik and Tesfai (1985) and Gafar et al. (2012) reported similar effects of pesticides on plant growth and soil. Also Farenhorst (2006) and Ferencz and Balog (2010) reported that most soils under field and vegetable crops and forests were contaminated with pesticides residues. Relyea (2005) reported that adsorption could be considered as one of the most important factors that affects fate of pesticide in soils and determines their distribution in the soil/water environment. Pimentel (1997) stated that without pesticide application the loss of fruits, vegetables and cereals from pest injury would reach 78\%, 54\% and $32 \%$, respectively. Crop loss from pests declines to $35 \%$ to $42 \%$ when pesticides are used

It could be concluded that usage of Malathion and Sevin at the recommended dose or lower may be helpful in cucumber production.

Table.1. Effect of Malathion on the vegetative growth (plant height, number of leaves, leaf area and shoot fresh and dry weights), of snake cucumber

\begin{tabular}{cccccc}
\hline Treatment & $\begin{array}{c}\text { Plant height } \\
(\mathrm{cm})\end{array}$ & $\begin{array}{c}\text { Number of } \\
\text { leaves/plant }\end{array}$ & $\begin{array}{c}\text { Leaf } \\
\text { area/plant }\left(\mathrm{cm}^{2}\right)\end{array}$ & $\begin{array}{c}\text { Shoot fresh } \\
\text { weight }(\mathrm{g})\end{array}$ & $\begin{array}{c}\text { Shoot dry } \\
\text { weight }(\mathrm{g})\end{array}$ \\
\hline $\begin{array}{c}\text { Control } \\
\text { Recommended dose } \\
(1.90) \mathrm{kgha}^{-1}\end{array}$ & 124.3 & 69 & 14.3 & 492.4 & 68.5 \\
$\begin{array}{c}\text { Lower dose } \\
(0.95) \mathrm{kgha}^{-1}\end{array}$ & 97.00 & 67 & 12.8 & 316.9 & 35.9 \\
$\begin{array}{c}\text { Higher dose } \\
(2.85) \mathrm{kgha}^{-1}\end{array}$ & 66.7 & 51 & 12.3 & 211.1 & 26.0 \\
\hline LSD 5\% & 36.00 & 30 & 10.2 & 124.0 & 15.6 \\
\hline
\end{tabular}


Table 2. Effect of Sevinn on the vegetative growth (plant height, number of leaves,Leaf area and shoot fresh and dry weights), of snake cucumber

\begin{tabular}{cccccc}
\hline Treatment & Plant height $(\mathrm{cm})$ & $\begin{array}{c}\text { Number of } \\
\text { leaves/plant }\end{array}$ & Leaf area/plant $\left(\mathrm{cm}^{2}\right)$ & $\begin{array}{c}\text { Shoot fresh } \\
\text { weight }(\mathrm{g})\end{array}$ & $\begin{array}{c}\text { Shoot dry } \\
\text { weight }(\mathrm{g})\end{array}$ \\
\hline $\begin{array}{c}\text { Control } \\
\begin{array}{c}\text { Recommended dose } \\
(1.90) \mathrm{kgha}^{-1}\end{array}\end{array}$ & 127.5 & 62.0 & 13.7 & 461.6 & 94.4 \\
$\begin{array}{c}\text { Lower dose } \\
(0.95) \mathrm{kgha}^{-1}\end{array}$ & 107.5 & 44.0 & 13.3 & 197.7 & 47.8 \\
$\begin{array}{c}\text { higher dose } \\
(2.85) \mathrm{kgha}^{-1}\end{array}$ & 73.67 & 35.0 & 12.2 & 116.7 & 33.2 \\
\hline LSD 5\% & 38.33 & 24.0 & 9.7 & 85.30 & 16.3 \\
\hline
\end{tabular}

Table 3. Effect of pesticides Malthion and Sevin on soil

\begin{tabular}{ccccccccccc}
\hline \multirow{2}{*}{ Pesticide } & Parameter & $\begin{array}{c}\text { Sand } \\
\%\end{array}$ & $\begin{array}{c}\text { Silt } \\
\%\end{array}$ & $\begin{array}{c}\text { Clay } \\
\%\end{array}$ & $\begin{array}{c}\mathrm{pH} \\
\mathrm{paste}\end{array}$ & $\begin{array}{c}\mathrm{ECe} \\
\mathrm{dSm}{ }^{-1}\end{array}$ & $\begin{array}{c}\mathrm{CEC} \\
\mathrm{cemol}(+) \mathrm{kg}^{-1}\end{array}$ & $\begin{array}{c}\text { O.C } \\
\%\end{array}$ & $\begin{array}{c}\text { Total } \\
\mathrm{N}(\%)\end{array}$ & $\begin{array}{c}\mathrm{P} \\
\mathrm{Ppm}\end{array}$ \\
\hline \multirow{3}{*}{ Malathion } & $\begin{array}{c}\text { Before } \\
\text { planting } \\
\text { After } \\
\text { planting }\end{array}$ & 13 & 32 & 55 & 7.7 & 0.4 & 50 & 0.9 & 0.14 & 6.1 \\
& 32 & 18 & 50 & 7.1 & 0.98 & 45 & 0.7 & 0.09 & 4.9 \\
\hline $\begin{array}{c}\text { Before } \\
\text { planting } \\
\text { After } \\
\text { planting }\end{array}$ & 15 & 35 & 57 & 7.8 & 0.5 & 55 & 0.8 & 0.17 & 6.3 \\
& 19 & 50 & 7.6 & 1.0 & 47 & 0.6 & 0.1 & 5.0 \\
\hline
\end{tabular}

\section{REFERENCES}

[1] Anonymous (2008). Annual report. Fedral Ministry of Agriculture and Forestry, Khartoum, Sudan

[2] Abdel-Gawad, A.A. (2001). Effect of Sevin on growth of carrot. Cairo University, Dar Elthgafa Press, Cairo, Egypt.

[3] Bartha, R., R.P. Lanzilotta and D. Pramer (1967). Stability and effects of some pesticides in soil. Appl. Environ. Microbiol. asm.asm.org content/15/167 (2013).

[4] Farenhorst, A. (2006). Importance of soil organic matter Fractions in soil-landscape and regional assessments of pesticide sorption and leaching in soil. Soil Sci. Soc. Am. J. 70(3), 1005-1012.

[5] Ferencz, L. and A, Balog. (2010). A pesticide survey in soil, water and foodstuffs from central Romania. Carpathian Journal of Earth and Environmental Sciences, 5(1), 111-118.

[6] Gafar M.O., Y.M., Ibrahim, H.A., Dawood, M.F. Awad Alla and W. Ahmed (2011). The Effect of Malathion (Organo Phosphate ) and Sevin (Carbamate) Application on Garlic Plant and Soil, Research Journal of Agriculture and Biological Sciences, 7(3): 332-334

[7] Gafar M.O., Y. M. I. Dagash, A-Z. Elhag and Y. O. Hassan (2011). Residual Effect of Malathion (Organophosphate) and Sevin (Carbamate) Application on Potato (Solanum tuberosum) American Journal of Experimental Agriculture 1(4): $226-230$

[8] Gafar M.O., Y. M. Dagash, M. Mustafa and O. M. Alzen
(2010). The Residual effect of Malathion (Organophosphate) and Sevin (Carbamate) application on sugar beet (Chenpodiaceae) Growth, Journal of Science and Technology 11 (2) ISSN 1605 - 427X (C) Sudan University of Science and Technology

[9] Gigliotti, C., and L, Allievi. (2001). Differential effects of the herbicides Bensulphuron and Cinosulphuron on soil microorganisms. Journal of Environmental Science and Health, Part B: Pesticides, Food Contaminants, and Agricultural Wastes 36(6), 775 - 782.

[10] Gilliom, R.J. (2007). Pesticides in U.S. Streams and Groundwater. Environmental Science and Technology 41(10), 3408-3414.

[11] Guo XH, Chen X, and Huang GX, et al. (2006). Pollution characteristcs of organochlorine pesticides in shallow surface water body of Pearl River Delta. Environ. Chem., 25(6): 798-799

[12] Lang, M., and Z, Cai. (2009). Effects of chlorothalonil and carbendazim on nitrification and denitrification in soils. Journal of Environmental Sciences 21(4), 458-467.

[13] Lichtenstein, E.P., W.F. Millingten and G.T.Cowley (1962). Effects of various insecticides on growth and respiration of plants. J. Agric. Food Chem. 10 (3), 251-256. Pubs. Acs.org. (2013).

[14] Longley, M., and N.W, Sotherton. (1997). Factors determining the effects of pesticides upon butterflies inhabiting arable farmland. Agriculture, Ecosystems and Environment 61(1), 1-12.

[15] Mallik, M.A.B. and K. Tesfai ( 1985). Pesticidal effects on soybean rhizobic symbiosis. Plant and Soil 85, 33-41. Springer.com (2013) 
[16] Maltby, L., and L, Hills. (2008). Spray drift of pesticides and stream macroinvertebrates: Experimental evidence of impacts and effectiveness of mitigation measures. Environmental Pollution 156(3), pp 1112-1120.

[17] Omer, I.S., (2001). Pesticides residues at Alfashir Distirct, West of Sudan.

[18] Pimentel, D. (2005). Environmental and Economic Costs of the Application of Pesticides Primarily in the United States. Environment, Development and Sustainability 7, 229-252.

[19] Potera, C. (2007). Agriculture: Pesticides disruption of nitrogen fixation. Environ Health Prospect 115(12)., 236-239
[20] Relyea, R.A. (2005). The impact of insecticides and herbicides on the biodiversity and productivity of aquatic communities. Ecological Applications 15(2), 618-627.

[21] Shahla, Y., and D'Souza, D. (2010). Effects of Pesticides on the Growth and Reproduction of Earthworm: A Review. Applied and Environmental Soil Science 2010.

[22] Zaki, M.M., (1978). The effect of chemical pesticides on the environment. Ain Shams University. 